\title{
Envase de vidrio en recto
}

\section{Glass bottle in the rectum}

\section{Marco Antonio Ayala-García ${ }^{1,2,3}$, Jorge Reyes Sánchez ${ }^{3}$}

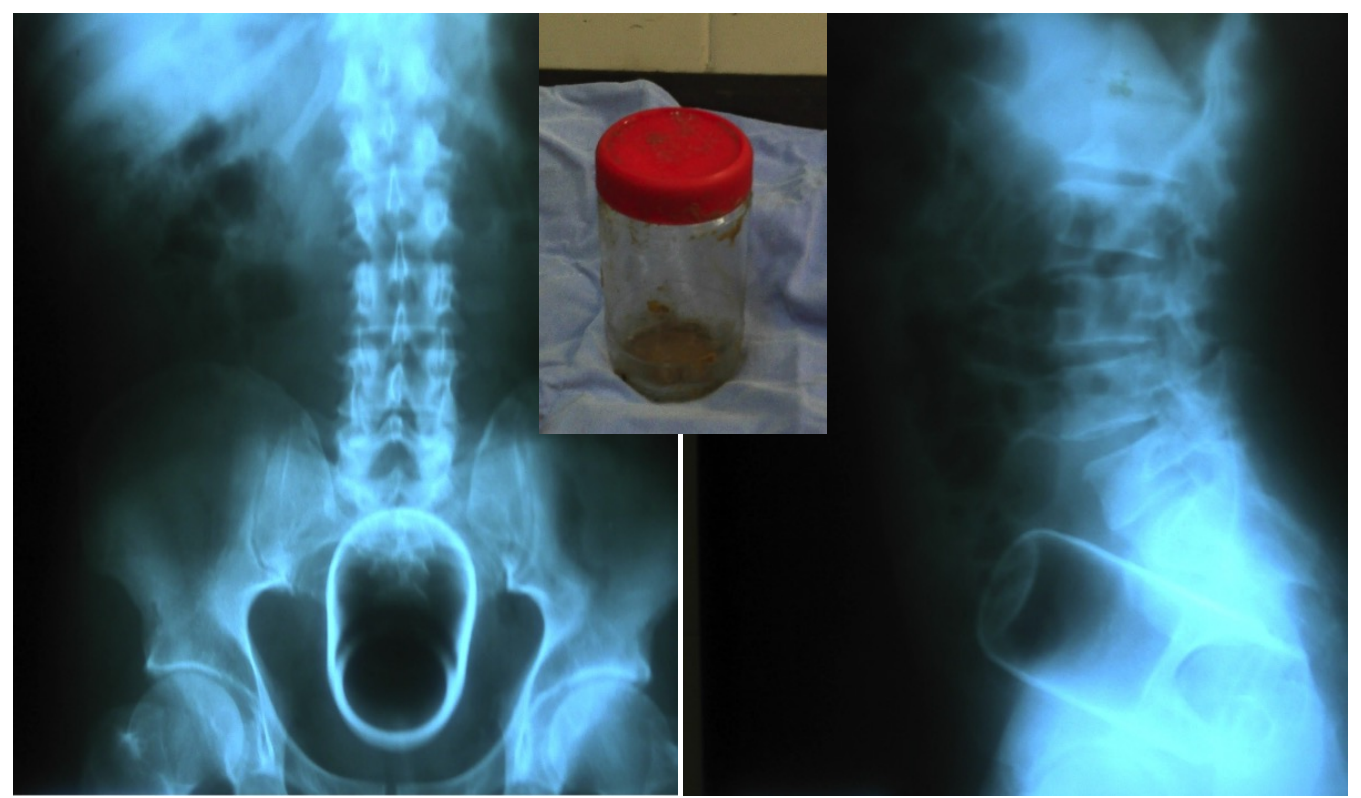

Varón de 65 años de edad que acudió a urgencias por presentar dolor a nivel rectal e imposibilidad para evacuar; al tacto rectal se palpaba objeto de consistencia firme. Se le realizó radiografía de abdomen anteroposterior y lateral cuyas imágenes se muestran. Se procedió a pasar al quirófano y bajo un bloqueo peridural, se dilató el ano digitalmente y con una maniobra de Kristeller se extrajo el envase de vidrio con los dedos índice y pulgar. El paciente fue dado de alta con analgésico vía oral posterior a la recuperación de la anestesia.

A 65-year-old male was admitted in to the emergency room due to rectal pain and inability to defecate, the rectal examination revealed a firm object. We show the anteroposterior and lateral plain abdominal films taken. The patient went to the operating room were using the Kristeller's maneuver a glass bottle was extracted using the thumb and index fingers. The patient was discharged with oral analgesics.

\section{Correspondencia}

Dr. Marco Antonio Ayala García

Hospital Regional de Alta Especialidad del Bajío

Blvd. Milenio \#130, Col. San Carlos La Roncha, CP 37660, León, Guanajuato, México.

Telefono 52 (477) 2414826 / Fax 52(477) 7413892

Correo electrónico: drmarcoayala@hotmail.com

Unidad de Investigación, Hospital Regional de Alta Especialidad del Bajío. León, Guanajuato, México.

Servicio de Cirugía, Hospital General Regional No. 58 del IMSS. Delegación Guanajuato, México

Comité de Investigación, Escuela de Medicina, Universidad Quetzalcóatl. Irapuato, Guanajuato, México. 